\title{
Rancang Bangun Sistem Rekomendasi Peminatan Fakultas Teknologi Informasi dan Komunikasi dengan Metode Analytical Hierarchy Process
}

\author{
Yosua Petra ${ }^{1}$, Seng Hansun ${ }^{2}$ \\ Program Studi Teknik Informatika, Fakultas Teknologi Informasi dan Komunikasi \\ Universitas Multimedia Nusantara \\ Jl. Boulevard Gading Serpong, Scientia Garden, Tangerang \\ E-mail:1'yosua.petra@hotmail.com, ${ }^{2}$ hansun@umn.ac.id
}

Masuk: 20 November 2015; Direvisi: 18 Desember 2015; Diterima: 21 Desember 2015

\begin{abstract}
The tight competition in these globalization era encourages university students to pick suitable specialization courses while studying in university. University students will not only gain the knowledge from those particular specialization courses but they will also get the practical skills and the certification, as well as improved talents. Students have to consult to one of the lecturers for guidance to pick the most suitable courses for the students. However this method is time consuming. For such reason, the main purpose of this research is to build a recommendation system that utilizes Analytical Hierarchy Process to allow students to decide the course specialization. This system is be built based on Android and PHP programming language to process the recommendation calculation. According to the questionnaire done, more than 50\% of the respondents confirm that this application has good accuracy rate, and as much as $40 \%$ respondents confirm that the application is able to provide course specialization recommendation that meets their preferences.
\end{abstract}

Keywords: Android, recommendation system, specialization course, university

\begin{abstract}
Abstrak. Persaingan ketat dalam era globalisasi ini mendorong para mahasiswa untuk memilih peminatan yang tepat selama duduk di bangku kuliah. Tidak hanya pengetahuan khusus yang akan diperoleh dalam peminatan tersebut, keterampilan praktis dan bakat serta sertifikasi yang ditawarkan dalam suatu peminatan harus dipertimbangkan untuk memilih peminatan yang terbaik bagi seorang mahasiswa. Selama ini, para mahasiswa harus berkonsultasi dengan dosen yang dapat membimbingnya memilih peminatan yang tepat. Namun demikian, metode ini memakan waktu yang lama. Untuk menanggulangi hal tersebut, tujuan utama penelitian ini adalah membangun suatu sistem rekomendasi yang menggunakan Analytical Hierarchy Process yang memungkinkan para mahasiswa memilih peminatan yang tepat. Sistem dibangun berbasis Android dan bahasa pemrograman PHP untuk memproses perhitungan rekomendasi. Berdasarkan hasil kuesioner yang dilakukan, lebih dari 50\% responden menyatakan bahwa aplikasi memiliki akurasi yang baik dan sebesar 40\% menyatakan bahwa aplikasi dapat memberikan saran peminatan berdasarkan preferensi mereka dengan sangat baik.
\end{abstract}

Kata Kunci: Android, sistem rekomendasi, peminatan, universitas

\section{Pendahuluan}

Dewasa ini, teknologi informasi terus merambah ke seluruh Indonesia. Terobosan demi terobosan terus diterapkan dalam kehidupan, baik dalam kebutuhan sehari-hari maupun dalam bidang komersial. Demikian pula dalam dunia kerja sekarang ini, keahlian dalam bidang teknologi informasi tertentu sudah menjadi suatu hal umum yang dibutuhkan pada saat melamar pekerjaan.Teknologi informasi terutama di bidang gadget yang semakin menjanjikan di masa kini telah membuka peluang bagi masyarakat untuk mengejar jenjang pendidikan perguruan tinggi di bidang Teknologi Informasi dan Komunikasi (TIK). Hal inidisebabkan oleh semakin maraknya perkembangan teknologi informasi di bidang komersial (e-commerce), serta semakin banyaknya persyaratan yang diajukan pada sebagian besar lowongan kerja untuk memiliki keahlian di bidang tertentu. Karena tingkat kelulusan yang cukup tinggi di tanah air, maka 
peminatan pada fakultas TIK yang memiliki fokus pada bidang tertentu semakin ditinjau dalam merencanakan masa depan (Edukasi Kompas, 2013).

Dalam memilih peminatan di fakultas TIK, terdapat beberapa kriteria yang perlu diperhitungkan seperti minat dari mahasiswa, prospek pekerjaan berdasarkan peminatan dan lainnya, yang dipertimbangkan dan disesuaikan dengan mahasiswa. Universitas Multimedia Nusantara menyediakan beberapa peminatan di fakultas TIK, yaitu peminatan Cisco, Game Development, Oracle,dan Sistem Aplikasi Perusahaan (SAP). Sering kali mahasiswa bingung dalam memilih peminatan yang sesuai dengan kebutuhan dan keinginannya, dan mahasiswa melakukan konsultasi kepada dosen untuk mendapatkan rekomendasi dalam memilih peminatan. Banyaknya konsultasi yang dilakukan karena jumlah mahasiswa yang tidak sedikit dapat menguras waktu dan tempat bagi mahasiswa maupun dosen, sehingga diperlukan cara yang lebih efektif agar dapat menjawab kebutuhan mahasiswa dalam pemilihan peminatan yang tepat tersebut.

Berdasarkan latar belakang masalah yang telah dijelaskan, maka penelitian ini dilakukan dengan tujuan untuk membuat sebuah aplikasi yang mampu memberikan rekomendasi yang memudahkan mahasiswa dalam memilih peminatan pada fakultas TIK.

\section{Tinjauan Pustaka}

\subsection{Penelitian Terdahulu}

Saat ini sudah terdapat banyak sekali metode yang dapat digunakan untuk mengambil keputusan dan memberikan rekomendasi, salah satunya adalah Analytical Hierarchy Process (AHP). AHP merupakan suatu metode untukmengambil keputusan yang mempertimbangkan kriteria-kriteria secara logis dan rasional, dengan mempertimbangkan data-data kualitatif seperti perasaan, minat, dan lainnya. Terdapat beberapa penelitian pendahulu yang telah memanfaatkan AHP sebagai metode pengambilan keputusan dalam memecahkan masalah yang dihadapi, seperti penelitian yang dilakukan oleh Sukenda dan Afrizone (2012) yang menggunakan AHP untuk membantu seorang pembeli dalam memilih suatu kendaraan (mobil) bekas, dan penelitian mengenai pemilihan siswa dalam mengikuti olimpiade sains tingkat Sekolah Menengah Atas yang dilakukan oleh Sutikno (2010), serta mendukung keputusan peminatan jurusan terhadap siswa SMA, dengan studi kasus SMA Negeri 15 Semarang yang dilakukan oleh Jasmin (2014).

\subsection{Sistem Rekomendasi}

Sistem rekomendasi adalah salah satu cabang dari sistem pendukung keputusan, dimana sistem rekomendasi merupakan suatu model aplikasi terhadap keinginan dan keadaan pengguna. Sistem rekomendasi akan memanfaatkan opini seseorang terhadap suatu produk atau pilihan dalam domain atau kategori tertentu, untuk membantu seseorang dalam memilih produk. Sistem rekomendasi perlu menggunakan model rekomendasi yang sesuai dengan keinginan pengguna untuk menentukan produk atau pilihan yang tepat (McGinty and Smyth, 2006). Sistem rekomendasi merupakan salah satu cara efektif untuk menangani permasalahan information overload (Itmazi \& Megias, 2008; Lee \& Kwon, 2008; Yang \& Chen, 2010) yang dapat digunakan untuk membantu pengguna dalam menentukan informasi yang relevan dari sejumlah besar informasi yang ada (Ghauth \& Abdullah, 2010; Huang, dkk., 2012).

\subsection{Analytical Hierarchy Process (AHP)}

AHP adalah suatu metode terstruktur untuk memecahkan masalah yang melibatkan variabel-variabel atau atribut-atribut keputusan, yang mana beberapa diantaranya bersifat kualitatif dan tidak dapat diukur secara langsung (Sutterfield, dkk., 2008). AHP memiliki landasan aksiomatik (Saaty, 1993) yang terdiri dari: (1) Reciprocal Comparison, yang berarti matriks perbandingan berpasangan yang terbentuk harus bersifat berkebalikan. Jika matriks A adalah $k$ kali lebih penting daripada $\mathrm{B}$, maka $\mathrm{B}$ adalah $1 / k$ kali lebih penting dari A. (2) Homogenity, yang berarti preferensi seseorang harus dapat dinyatakan dalam skala terbatas atau dengan kata lain elemen-elemennya dapat dibandingkan satu sama lain. Kalau aksioma ini tidak 
dapat dipenuhi maka elemen-elemen yang dibandingkan tersebut tidak homogeneous dan harus dibentukkan suatu kelompok elemen yang baru. (3) Dependence yang berarti setiap jenjang atau level saling berkaitan (complete hierarchy) walaupun mungkin terdapat hubungan tidak sempurna (incomplete hierarchy). (4) Expectation yang berarti menampilkan penilaian yang bersifat ekspektasi dan preferensi dari pengambilan keputusan. Penilaian dapat merupakan data kualitatif maupun data kuantitatif.

Prinsip dasar AHP adalah sbb (Saaty, 2008): (1) Penyusunan Hierarki. Persoalan yang akan diselesaikan diuraikan menjadi unsur-unsurnya yaitu kriteria dan alternatif, kemudian disusun menjadi hirarki. (2) Penilaian Kriteria dan Alternatif. Untuk membuat pairwise comparison, Saaty membuat skala fundamental yang diturunkan berdasarkan riset psikologis atas kemampuan individu dalam membuat suatu perbandingan secara berpasangan terhadap beberapa elemen yang akan diperbandingkan. (3) Penentuan Prioritas. Untuk setiap kriteria dan alternative perlu dilakukan perbandingan berpasangan atau biasa disebut pairwise comparisons. Nilai-nilai perbandingan relative kemudian diolah untuk menentukan peringkat relatif dari seluruh alternative. Baik kriteria kualitatif maupun kriteria kuantitatif dapat dibandingkan sesuai dengan bobot yang telah ditentukan untuk menghasilkan bobot dan prioritas dihitung dengan manipulasi matriks atau melalui penyelesaian matematika. (4) Konsistensi Logis. Semua elemen dikelompokkan secara logis dan diperingkatkan secara konsisten sesuai dengan suatu kriteria yang logis.

Langkah-langkah penyelesaian AHP adalah sebagai berikut (Latifah, 2005): (1) Perumusan Masalah. Untuk menyelesaikan masalah, maka perlu dilakukan tiga langkah: (a) Penentuan saran yang ingin dicapai. (b) Penentuan kriteria pemilihan. (c) Penentuan alternative pilihan. (2) Pembobotan kriteria. Untuk menentukan bobot kriteria dapat dilakukan dengan cara: (a) Penentuan bobot secara sembarang. (b) Membuat skala interval untuk menentukan ranking setiap kriteria. (c) Dengan menggunakan prinsip AHP, yaitu perbandingan berpasangan (Pairwise Comparison), tingkat kepentingan suatu kriteria relatif terhadap kriteria lain dapat dinyatakan dengan jelas. (3) Penyelesaian dengan Manipulasi Matriks. Setelah melakukan perbandingan, matriks kemudian diubah kedalam definisi matriks untuk diolah dalam menentukan bobot dari kriteria, yaitu dengan menentukan nilai Eigen (Eigen Vector). Prosedur untuk mendapatkan nilai Eigen adalah. (a) Kuadratkan matriks tersebut. Hitung jumlah nilai dari setiap baris, kemudian melakukan normalisasi. (b) Hentikan proses bila ada perbedaan antara jumlah dari dua perhitungan lebih kecil dari suatu nilai batas tertentu. (c) Pembobotan alternatif. Matriks berpasangan dan alternatif-alternatif dari setiap kriteria kemudian disusun untuk dapat dianalisis, maka jawaban dapat diperoleh dengan jalan mengalikan matriks bobot kriteria. (d) Penyelesaian dengan persamaan matematik.

Ada tiga langkah untuk menentukan besarnya bobot yang dimulai dari kasus khusus yang sederhana sampai dengan kasus-kasus umum. Langkah 1 dapat dilihat pada Persamaan 1 dimana $W_{i}=$ bobot input dalam baris dan $W_{j}=$ bobot input dalam lajur. Langkah 2 dapat dilihat pada Persamaan 2, dan untuk kasus-kasus umum mempunyai bentuk sebagaimana diperlihatkan dalam Persamaan 3.

$$
\begin{aligned}
& W_{i} / W_{j}=a_{i j}(i, j=1,2, \ldots, n) \\
& W_{i}=a_{i j} W_{j}(i, j=1,2, \ldots, n) \\
& W_{i}=\frac{1}{n} \sum_{j=1}^{n} a_{i j} W_{j}(i, j=1,2, \ldots, n)
\end{aligned}
$$

Langkah 3, bila perkiraan $a_{i j}$ baik akan cenderung untuk dekat dengan nisbah $W_{i} / W_{j}$. Jika $n$ juga berubah maka $n$ diubah menjadi $\lambda \max$, maka diperoleh Persamaan 4. Pengolahan horizontal digunakan untuk menyusun prioritas elemen keputusan setiap tingkat hirarki keputusan. Tahapannya menurut Saaty (1993) adalah: (a) Perkalian baris (z) dengan Persamaan 5, (b) Perhitungan vektor prioritas atau vektor Eigen dengan Persamaan 6, dimana $e V P_{i}$ adalah elemen vektor prioritas ke- $i$. (c) Perhitungan nilai Eigen maksimum dengan Persamaan 7, Persamaan 8 sampai Persamaan 9, dimana $V B_{i}$ untuk $\mathrm{i}=1,2, \ldots, \mathrm{n}$, dan $\mathrm{VA}=\mathrm{VB}=$ vektor antara. 
(d) Perhitungan Konsistensi (CI). Pengukuran ini dimaksudkan untuk mengetahui konsistensi jawaban yang berpengaruh kepada kesahihan hasil (Persamaan 10). Untuk mengetahui apakah $\mathrm{CI}$ dengan besaran tertentu cukup baik atau tidak, perlu diketahui rasio yang dianggap baik yaitu apabila $\mathrm{CR} \leq 0.1$ (Persamaan 11).

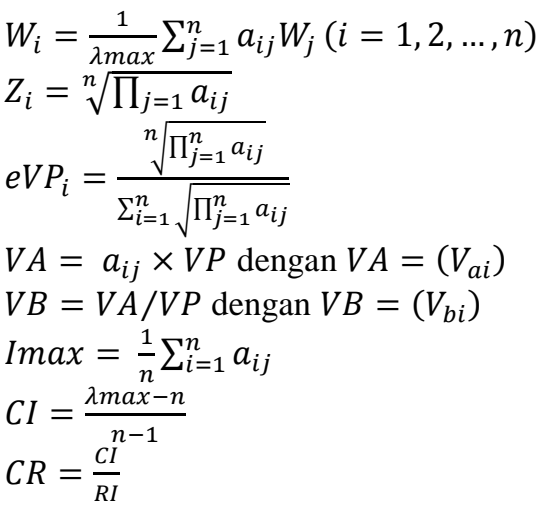

Nilai RI merupakan nilai random indeks yang dikeluarkan oleh Oak Ridge laboratory sebagaimana ditunjukkan oleh Tabel 1.

Tabel 1. Nilai Random Inkonsistensi (Karimi, dkk., 2011)

\begin{tabular}{cc}
\hline Ukuran Matriks (n) & Indeks Konsistensi Acak (RI) \\
\hline 1 & 0 \\
\hline 2 & 0 \\
\hline 3 & 0,58 \\
\hline 4 & 0,9 \\
\hline 5 & 1,12 \\
\hline 6 & 1,24 \\
\hline 7 & 1,32 \\
\hline 8 & 1,41 \\
\hline 9 & 1,45 \\
\hline
\end{tabular}

Dalam metode AHP, kelompok memutuskan struktur hirarki keputusan yang mengandung $n$ pilihan keputusan sesuai dengan masalah dan solusi yang diinginkan. Tiap individu pengambil keputusan $(t)$ menentukan preferensi relatif mereka $\left(a_{i j}^{t}=w_{i} / w_{j}\right)$ terhadap pasangan pilihan keputusan $i$ dan $j(i j=1, \ldots, n)$, sehingga diperoleh matriks $A^{t}$ dengan elemen $a_{i j}^{t}$. Misal, $w^{t}=\left(w_{1}^{t}, \ldots, w_{n}^{t}\right)$ adalah vektor bobot yang dinormalisasi, $w_{i}^{t} / w_{j}^{t}$ sama dengan $a_{i j}^{t}$ dan $w^{t}$, dan dapat diperoleh dengan memecahkan masalah nilai Eigen pada Persamaan 12, dimana $\lambda \max ^{t}$ merupakan nilai Eigen terbesar dari $A^{t}$ sehingga $\sum_{j} w_{j}^{t}=\operatorname{dan} w_{j}^{t} \geq 0$. Kemudian dilakukan perhitungan rasio konsistensi $(C R)$ untuk menentukan tingkat inconsistency dari prefensi tiap pengambil keputusan (Persamaan 13), dimana CI merupakan indeks konsistensi dari $R I$ merupakan indeks random inconsistency.Jika tingkat inconsistency tidak dapat diterima $(C R \geq 0,1)$, pengambil keputusan disarankan merevisi dan menghitung kembali prefensi relatif yang digunakan dalam perhitungan AHP.

$A^{t} * w^{t}=\lambda \max ^{t} * w^{t}$

$C R=\frac{C I}{R I}=\frac{(\lambda \max -n) /(n-1)}{R I}$

Dalam penelitian ini, kriteria-kriteria yang digunakan didapatkan dari hasil kuesioner dan wawancara bersama empat orang pakar yang mewakili bidang peminatan yang ada di Universitas Multimedia Nusantara. Kriteria-kriteria yang telah disetujui adalah sebagai berikut. (1) Nilai Mata Kuliah. Untuk setiap peminatan di fakultas TIK, mahasiswa diharuskan lulus pada beberapa mata kuliah dengan nilai minimal yang sudah ditentukan. Hal ini ditentukan 
untuk mahasiswa karena terdapat ilmu pada mata kuliah tertentu yang diperlukan sebelum mengambil peminatan di fakultas TIK Universitas Multimedia Nusantara. Selain itu, terdapat juga mata kuliah yang bersangkutan dengan peminatan, namun masih berkaitan dengan peminatan yang ada. Nilai dari mata kuliah yang digunakan adalah mata kuliah yang berkaitan dengan peminatan. (2) Minat atau Interest. Ketertarikan mahasiswa dalam suatu bidang di informasi teknologi dan komunikasi juga diperhitungkan dalam menentukan rekomendasi yang akan diberikan. (3) Prospek Masa Depan. Prospek masa depan dari peminatan merupakan salah satu kriteria perhitungan rekomendasi. Kriteria prospek masa depan dibagi menjadi tiga subkriteria, yaitu gaji harapan atau fresh graduate salary, rating sertifikasi untuk peminatan, dan biaya yang dikeluarkan untuk mengikuti ujian entry level certification. (4) Tingkat Kesulitan. Dalam menentukan rekomendasi, tingkat kesulitan dari mata kuliah peminatan tersebut juga turut diperhitungkan. Hierarki AHP dari kriteria-kriteria yang digunakan pada penelitian ini terdapat pada Gambar 1.

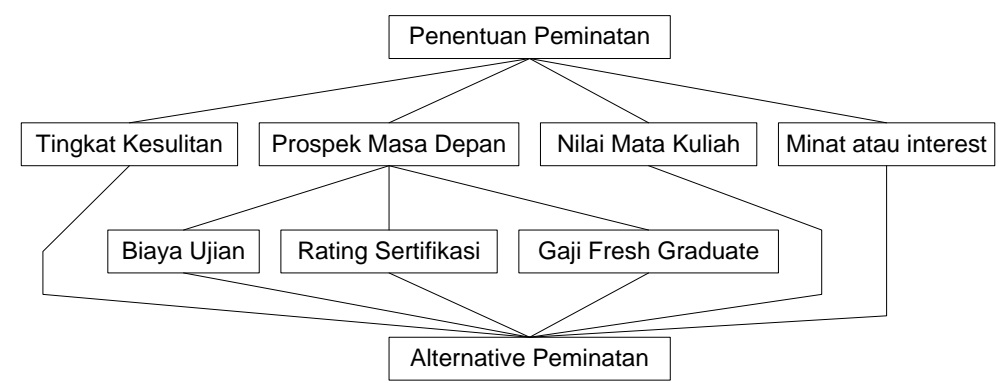

Gambar 1. Hierarki AHP Peminatan Fakultas TIK

\subsection{Normalisasi Min-Max}

Normalisasi min-max adalah suatu teknik normalisasi untuk mengubah data-data yang belum memiliki standar menjadi suatu data yang sudah dinormalisasi dengan transformasi linear dan tidak mengubah korelasi dari nilai data asli (Jain \& Bhandare, 2011). Tujuan dari penggunaan algoritma min-max adalah untuk melakukan normalisasi data kuantitatif menjadi data dalam bentuk skala Saaty. Rumus normalisasi ini dapat dilihat pada Persamaan 14.

$v_{i}^{\prime}=\frac{v_{i}-\min _{A}}{\max _{A}-\min _{A}}\left(n e w_{-} \max _{A}-n e w_{-} \min _{A}\right)+n e w_{-} \min _{A}$

\section{Rancangan Alur Kerja Aplikasi}

Sistem rekomendasi peminatan fakultas TIK di UMN diakses melalui client application yang tersedia pada perangkat Android yang digunakan. Setelah melakukan login, user dapat memilih menu-menu yang tersedia pada tampilan menu utama. Jika user memilih menu mengambil tes peminatan, maka sistem akan menerima input user, melakukan perhitungan AHP dan menampilkan hasil rekomendasi.

Pada proses perhitungan AHP, sistem akan mendapatkan bobot matriks pairwise dan matriks bobot kriteria tetap dari database, dan melakukan proses normalisasi untuk digunakan pada perhitungan selanjutnya. Setelah mendapatkan matriks pairwise dan matriks bobot kriteria tetap, sistem akan mendapatkan informasi nilai user dari database untuk digunakan dalam perhitungan AHP. Setelah itu, sistem akan mendapatkan input preferensi user untuk dijadikan sebagai bobot input kriteria interest dan tingkat kesulitan. Setelah mendapatkan semua input preferensi user, pembuatan matriks kriteria dinamis dan normalisasi matriks kriteria dinamis dilakukan. Setelah mendapatkan seluruh matriks kriteria, dilakukan perhitungan prioritas vektor untuk matriks pairwise dan matriks kriteria terhadap peminatan. Pada tahap selanjutnya, perkalian matriks pairwise dan matriks kriteria dilakukan untuk mendapatkan nilai peminatan terhadap goal, peminatan dengan nilai tertinggi direkomendasikan kepada user. Proses perhitungan dijabarkan pada Gambar 2. 


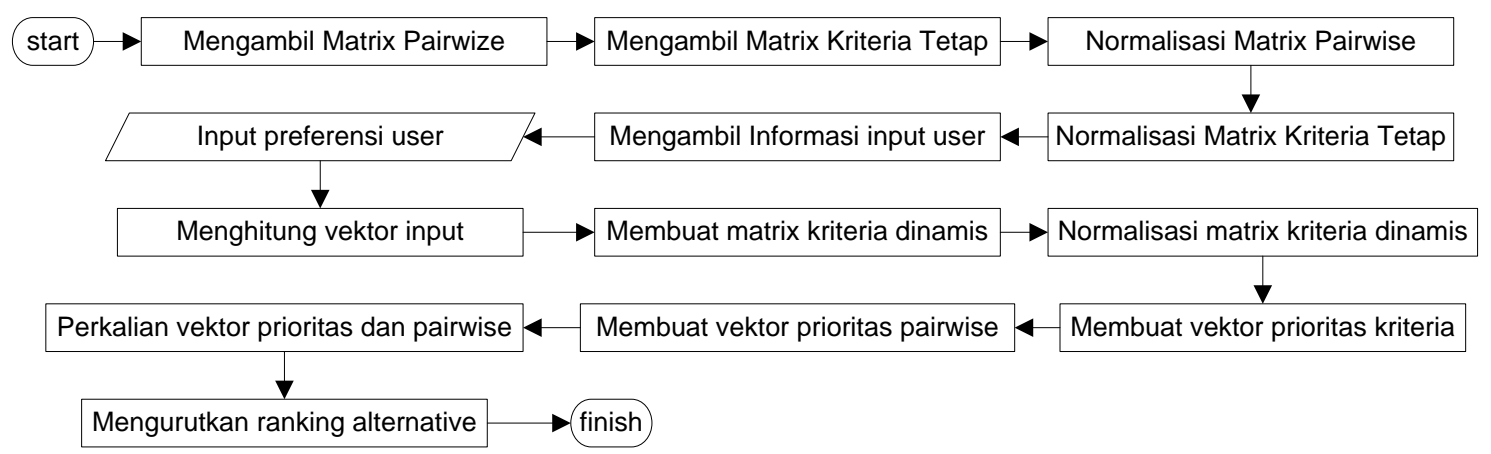

Gambar 2. Diagram Alir Proses Perhitungan AHP

\section{Uji Coba dan Pembahasan}

Uji coba dilakukan dengan tujuan untuk melihat seberapa besar peranan aplikasi dalam membantu mahasiswa untuk menentukan pilihan peminatan berdasarkan hasil rekomendasi yang dihasilkan oleh aplikasi ini. Data uji coba untuk sistem rekomendasi ini berasal dari dua sampel data milik responden yang merupakan mahasiswa Teknik Informatika di UMN yang ingin mengambil peminatan Oracle dan mahasiswa Teknik Informatika yang berminat untuk mengambil jurusan SAP.

Uji coba dilakukan dengan melakukan input data sesuai dengan preferensi responden. Berikut adalah hasil rekomendasi peminatan responden pertama pada Tabel 2. Uji coba responden kedua juga dilakukan dengan melakukan input preferensi responden, berikut ini adalah hasil rekomendasi peminatan responden kedua dijabarkan pada Tabel 3.

Tabel 2. Tabel Hasil Rekomendasi Respoden 1

\begin{tabular}{lc}
\hline Nama Peminatan & Prioritas Terhadap Goal \\
\hline CISCO & 0,27897 \\
\hline Oracle & 0,28195 \\
\hline SAP & 0,17269 \\
\hline Game Development & 0,26639 \\
\hline Peminatan Terbaik & Oracle \\
\hline
\end{tabular}

Tabel 3. Tabel Hasil Rekomendasi Responden 2

\begin{tabular}{lc}
\hline Nama Peminatan & Prioritas vs Goal \\
\hline CISCO & 0,28982 \\
\hline Oracle & 0,26413 \\
\hline SAP & 0,25016 \\
\hline Game Development & 0,19589 \\
\hline Peminatan Terbaik & CISCO \\
\hline
\end{tabular}

Setelah melakukan uji coba, responden berpendapat bahwa aplikasi Android ini dapat membantu mahasiswa menentukan peminatan, namun responden juga mengatakan bahwa meskipun cukup akurat, mata kuliah sebelum semester empat yang berkaitan dengan rekomendasi masih belum mencakup bidang peminatan secara keseluruhan. Selain itu, tampilan pada saat memilih minat atau interest yang disukai masih belum memiliki informasi yang cukup untuk minat atau interest yang belum diketahui atau asing bagi responden. Menurut responden, pada tampilan memilih tingkat kesulitan, slider untuk memilih preferensi kesulitan memiliki terlalu banyak step untuk digunakan dalam memilih tingkat kesulitan.

Tahap selanjutnya dalam uji coba adalah dengan menggunakan kuesioner yang diikuti oleh total responden berjumlah 30 responden. Banyaknya responden berjumlah 30 agar dengan jumlah minimal ini, distribusi skor atau nilai akan lebih mendekati kurva normal (Daihani, 2001). Semua responden berasal dari mahasiswa fakultas TIK di UMN.

Parameter pertama yang diujikan yaitu kemudahan dan kenyamanan responden dalam menggunakan aplikasi rekomendasi peminatan. Sebanyak $90 \%$ responden menyatakan mudah dan nyaman dalam menggunakan aplikasi, sedangkan $10 \%$ menyatakan sebaliknya. Parameter kedua adalah desain dari aplikasi. Sebesar $93.33 \%$ responden berpendapat aplikasi memiliki desain yang baik, sedangkan sebesar $6.67 \%$ berpendapat bahwa aplikasi memiliki desain yang tidak baik. Parameter ketiga yaitu tingkat keakuratan dari aplikasi rekomendasi peminatan ini. Untuk mengukur parameter kecocokan rekomendasi, skala Likert dengan skala poin sebanyak lima dapat digunakan untuk merepresentasikan kecocokan (Likert, 1932). Skala Likert dapat digunakan untuk mengukur sikap atau tingkah laku dalam cara ilmiah yang dapat diterima dan 
divalidasi (Edmondson, 2005; Joshi, dkk., 2015). Sebanyak 20\% responden menyatakan bahwa bahwa aplikasi rekomendasi peminatan ini memberikan rekomendasi peminatan yang sangat baik. Sebanyak 30\% responden menyatakan tingkat keakuratan baik, $23.33 \%$ menyatakan cukup, 20\% menyatakan tidak baik, dan $6.67 \%$ menyatakan sangat tidak baik. Pada Tabel 4 dijabarkan tingkat akurasi aplikasi menurut responden menggunakan skala Likert. Parameter terakhir yaitu manfaat dari aplikasi rekomendasi peminatan khususnya untuk membantu mahasiswa dalam memilih peminatan. Sebesar $16.67 \%$ responden memberikan skala rating dengan nilai lima yang mendeskripsikan bahwa aplikasi ini sangat baik untuk membantu dalam memilih peminatan, sedangkan sebanyak $23.33 \%$ menyatakan aplikasi ini baik dalam membantu memilih peminatan. Sebesar $33.33 \%$ menyatakan cukup baik, $16.67 \%$ menyatakan tidak baik dan sebesar $10 \%$ menyatakan sangat tidak baik. Pada Tabel 5 dijabarkan manfaat aplikasi menurut responden menggunakan skala Likert.

Tabel 4. Keakuratan Menurut Responden dalam Skala Likert

\begin{tabular}{lccc}
\hline Pilihan & Poin Skala Likert & Jumlah & Total \\
\hline Sangat Baik & 5 & 6 & 30 \\
\hline Baik & 4 & 9 & 36 \\
\hline Cukup & 3 & 7 & 21 \\
\hline Tidak Baik & 2 & 6 & 12 \\
\hline Sangat Tidak Baik & 1 & 2 & 2 \\
\hline Average & $101 / 30=3,66667$ & & \\
\hline
\end{tabular}

Tabel 5. Manfaat Menurut Responden dalam Skala Likert

\begin{tabular}{lccc}
\hline Pilihan & Poin Skala Likert & Jumlah & Total \\
\hline Sangat Baik & 5 & 5 & 25 \\
\hline Baik & 4 & 7 & 28 \\
\hline Cukup & 3 & 10 & 30 \\
\hline Tidak Baik & 2 & 5 & 10 \\
\hline Sangat Tidak Baik & 1 & 3 & 3 \\
\hline Average & \multicolumn{3}{c}{$96 / 30=3,2$} \\
\hline
\end{tabular}

\section{Kesimpulan}

Berdasarkan hasil rancang bangun dan uji coba yang telah dilakukan, dapat disimpulkan bahwa metode AHPdapat diterapkan pada aplikasi sistem rekomendasi peminatan fakultasTIK UMN, dengan menggunakan kriteria nilai mata kuliah, tingkat kesulitan, kecocokan interest atau minat, serta prospek masa depan yang memiliki sub-kriteria biaya ujian entry level, rating sertifikasi dan salary fresh graduate pada peminatan sebagai preferensi user.

Aplikasi dapat bermanfaat untuk membantu mahasiswa dalam menentukan peminatan yang diambil pada semester lima. Kesimpulan ini dirumuskan berdasarkan hasil uji coba melalui kuesioner. Rata-rata tingkat kecocokan aplikasi untuk poin sangat cocok dan cocok telah mencapai 50\% dari seluruh responden. Sebesar 30\% responden menyatakan bahwa aplikasi ini memiliki tingkat kecocokan atau keakuratan yang baik dan sebesar $20 \%$ menyatakan sangat baik, dengan rata-rata poin skala Likert dengan skala satu hingga lima untuk parameter tingkat kecocokan adalah sebesar 3,67, yang dapat diartikan bahwa aplikasi ini telah menghasilkan hasil rekomendasi peminatan yang sesuai dengan preferensi responden. Sebesar $23,33 \%$ menyatakan bahwa aplikasi memiliki manfaat yang baik dan sebesar $16,67 \%$ menyatakan bahwa aplikasi ini memiliki manfaat yang sangat baik dalam membantu mahasiswa dalam memilih peminatan pada semester lima dengan rata-rata skala Likert sebesar 3,2.

\section{Referensi}

Daihani, D.U. 2001. Komputerisasi Pengambilan Keputusan. Jakarta: Elex Media Komputindo. Edmondson. D.R. 2005. Likert Scales: A History. Proceedings of the $12^{\text {th }}$ Conference on Historical Analysis and Research in Marketing (CHARM), California, USA, 28 April-1 May 2005.

Edukasi Kompas. 2013. Bagaimana Prospek Karier Lulusan Teknik Informatika?, (Online), (edukasi.kompas.com/read/2013/07/16/1657312/Bagaimana.Prospek.Karir.Lulusan.Tek nik.Informatika, diakses 08 Oktober 2014).

Ghauth, K.I., \& Abdullah, N.A. 2010. Learning Materials Recommendation using Good Learners' Ratings and Content-Based Filtering. Educational Technology Research and Development, 58(6): 711-727.

Huang, Y-M., Liu, C-H., Lee, C-Y., Huang, Y-M. 2012. Designing a Personalized Guide Recommendation System to Mitigate Information Overload in Museum Learning. 
Educational Technology \& Society, 15(4): 150-166.

Itmazi, J., \& Megias, M. 2008. Using Recommendation Systems in Course Management Systems to Recommend Learning Objects. International Arab Journal of Information Technology, 5(3): 234-240.

Jain, Y.K., \& Bhandare, S.K. 2011. Min Max Normalization Based Data Perturbation Method for Privacy Protection. International Journal of Computer \& Communication Technology, 2(8): 45-50.

Jasmin, A.A. 2014. Implementasi Metode Analytical Hierarchy Process dalam Mendukung Keputusan Peminatan Jurusan Terhadap Siswa SMA di SMA Negeri 15 Semarang. Skripsi. Semarang: Universitas Dian Nuswantoro.

Joshi, A., Kale, S., Chandel, S., \& Pal, D.K. 2015. Likert Scale: Explored and Explained. British Journal of Applied Science \& Technology, 7(4): 396-403.

Karimi, A.R., Mehrdadi, N., Hashemian, S.J., Bidhendi, G.R.N., Moghaddam, R.T. 2011. Selection of Wastewater Treatment Process based on the Analytical Hierarchy Process and Fuzzy Analytical Hierarchy Process Methods. International Journal of Environmental Science \& Technology, 8 (2): 267-280.

Latifah, S. 2005. Prinsip-Prinsip Dasar Analytical Hierarchy Process, (Online), (library.usu.ac.id/download/fp/hutan-siti11.pdf, diakses tanggal 18 Desember 2015).

Lee, K.C., \& Kwon, S. 2008. Online Shopping Recommendation Mechanism and Its Influence on Consumer Decisions and Behaviors: A Causal Map Approach. Expert System with Applications, 35(4): 1483-1493.

Likert, R. 1932. A Technique for the Measurement of Attitudes. Archives of Psychology, 140 (22): 5-55.

McGinty, L., \& Smyth, B. 2006. Adaptive Selection: Analysis of Critiquing and Preference Based Feedback in Conversational Recommender System. International Journal of Electronic Commerce, 11(2): 35-57.

Saaty, T.L. 1993. Pengambilan Keputusan Bagi Para Pemimpin, Proses Hirarki Analitik untuk Pengambilan Keputusan dalam Situasi yang Kompleks. Jakarta: PT. Pustaka Binaman Pressindo.

Saaty, T.L. 2008. Decision Making with the Analytical Hierarchy Model. International Journal of Services Sciences, 1(1): 83-98.

Sukenda dan Afrizone, Z.P. 2012. Sistem Pendukung Keputusan untuk Memilih Kendaraan Bekas dengan Menggunakan Metode Analitic Hierarchy Process (AHP), (Online), (http://repository.widyatama.ac.id/xmlui/handle/123456789/1917, diakses tanggal 18 Desember 2015).

Sutikno. 2010. Sistem Pendukung Keputusan Metode AHP untuk Pemilihan Siswa dalam Mengikuti Olimpiade Sains di Sekolah Menengah Atas. Prosiding Seminar Nasional Ilmu Komputer Universitas Diponegoro 2010, pp.183-192.

Sutterfield, J.S., Swirsky, S., \& Ngassam, C. 2008. Project Management Software Selection using Analytical Hierarchy Process. Academy of Information and Management Sciences Journal, 11(2): 79-93.

Yang, J.C., \& Chen, S.Y. 2010. Investigation of Learners' Perceptions for Video Summarization and Recommendation. Interactive Learning Environments, 20(4): 369385 . 